\title{
Clinical Psychology: Chosen Topics
}

\author{
Jesús Dueñas Becerra* \\ Honorary Partner, Scuola Romana Rorschach, Italy
}

*Corresponding author: Jesús Dueñas Becerra, Honorary Partner, Scuola Romana Rorschach, Italy.

To Cite This Article: Jesús Dueñas Becerra. Clinical Psychology: Chosen Topics. Am J Biomed Sci \& Res. 2019 - 6(1). AJBSR.MS.ID.000987. DOI: 10.34297/AJBSR.2019.06.000987.

Received: 眥 September 11, 2019; Published: 眥 October 31, 2019

\section{Editorial}

The theory without practice is pure verbalism; practice without mere empiricism theory Father Felix Varela

Mr. Juan Donaldo Quintilian Mendoza, assistant professor of the Faculty of Psychology of the University of Havana, is the author of the book Clinical Psychology: selected topics, published by the Scientific-Technical Editorial.

In that text, written with professionalism and love of the science of the spirit, the also head of the Department of Psychology of the Psychiatric Hospital of Havana Cdte. Dr. Eduardo Bernabé Ordaz, ventures into the most dissimilar fields of Clinical Psychology, whose exercise has been delivered in body, mind and soul, because, like the priest Félix Varela, José Martí and Don Enrique José Varona, founding fathers of Cuban psychology, perceives our noble profession as a nutritious source of ethics, culture, humanism and spirituality.

With support in the principle defended by Humanist Psychology that man is an indivisible bio-psycho-socio-cultural and spiritual unit, Professor Quintana Mendoza dissects - with sharp scalpel each and every one of the basic components on which structure the human personality, as well as the internal and external factors that influence it ... and enrich or disturb it. Indispensable requirement to know the person's intimate essence and also the psychogenic or organic character of the conditions he suffers when the bio-psychosocio-cultural and spiritual balance in which health is sustained is altered, defined not as the absence of physical illness or mental, but as a state of psychological, social and spiritual well-being, which characterizes those who live in peace and harmony with their self, with the other and with the natural environment where they carry out their daily activities.

With that theoretical-methodological arsenal in menti, the colleague Quintana Mendoza explores - with fine smell - almost all the edges that show personality disorders; controversial and controversial entity, both in the field of Clinical Psychology, and in the field of Psychiatry.

This work makes available to professionals and students of these discipline the clinical-psychological and psychologicalforensic findings of the research developed and published by the author in Cuban and foreign journals.

On the other hand, the analytical-synthetic reading of this text encourages us to perceive - from an objective-subjective perspective par excellence - how the social-economic reality, which today faces the largest island of the Antilles, as a sequel to the genocidal blockade American, the disintegration of the socialist bloc of Eastern Europe, the disappearance of the Soviet Union and the mental "marabou" that paralyzes the development of our society, influences the personality dynamics of those who inhabit - against wind and tide - in the Indomitable Caribbean caiman, and how that situation affects the value system on which the basic personality of the Cuban is built.

According to Professor Juan Donaldo Quintana Mendoza, in this dialectical interrelation of economic-social, educational, psychological, ethical-moral and spiritual factors, the scientific explanation of the psychopathization or sociopathization of the personality of many members of Cuban society should be sought. current. People who, until more than twenty years ago, were individuals whose integrity was not debatable, from any point of view, and today they have committed crimes, have bordered the limits of criminal activity or have contaminated and dehumanized their soul with petty passions: hate, envy and sickly worship to have, among others.

\section{Conclusion}

I conclude this review with a Martian aphorism: "It's good books, give what to talk about." You, future readers, have the floor. 